\title{
The hidden experience of nursing professionals sued for error
}

\author{
A experiência oculta do profissional de enfermagem processado por erro \\ La experiencia oculta del profesional de enfermería procesado por error
}

How to cite this article:

Souza VS, Matsuda LM, Freitas GF, Marcon SS, Costa MAR. The hidden experience of nursing professionals sued for error. Rev Esc Enferm USP. 2021;55:e03668. doi: https://doi.org/10.1590/S1980-220X2019036703668

\section{Verusca Soares de Souza ${ }^{1}$ \\ Laura Misue Matsuda² \\ Genival Fernandes de Freitas ${ }^{3}$ \\ Sonia Silva Marcon ${ }^{2}$ \\ D Maria Antônia Ramos Costa ${ }^{4}$ \\ ${ }^{1}$ Universidade Federal do Mato Grosso do Sul, Campus Coxim, Coxim, MS, Brazil. \\ ${ }^{2}$ Universidade Estadual de Maringá, Departamento de Enfermagem, Maringá, PR, Brazil. \\ ${ }^{3}$ Universidade de São Paulo, Escola de Enfermagem, Departamento de Orientação Profissional, São Paulo, SP, Brazil. \\ ${ }^{4}$ Universidade Estadual do Paraná, Campus Paranavaí, Paranavaí, PR, Brazil.}

\begin{abstract}
Objective: To understand the experience of judicialization due to error from the viewpoint of nursing professionals. Method: Qualitative study with two nursing professionals sued for error in a state in southern Brazil. The data were collected between January and June 2018 through an online survey and analyzed with the Oral History technique. Results: The reports discussed the experience of error and its influence on professional practice. The perception of being unable to intervene in errors and the lack of support from institutions and professional associations were mentioned as causes of emotional suffering, a feeling of injustice, and revolt. Nonetheless, both participants mentioned receiving support from the local health sector union and hoping to carry on with their profession. Conclusion: Emotional suffering caused by judicialization is amplified by a feeling of helplessness regarding error prevention and lack of institutional support.
\end{abstract}

\section{DESCRIPTORS}

Nursing; Patient Harm; Patient Safety; Legislation, Nursing; Stress, Psychological; Occupational Health. 


\section{INTRODUCTION}

Judicialization regarding errors in nursing is still a seldom discussed theme in scientific publications. Studies which have analyzed nursing errors, disseminated through television or electronic media, point a higher involvement of patients with their own security, claiming rights when feeling victimized in any manner and filing occurrence reports ${ }^{(1-2)}$. Error complaints in the health area are thus presumed to be presented to the Brazilian justice system, but little is known about how such suits proceed.

Among medical professionals, judicialization regarding malpractice accusations are becoming an object of study. Research conducted in Taiwan identified that this results mostly in indemnity, especially in obstetric and surgical procedures $^{(3)}$. In France, most complaints involved surgeons and were due to failure in providing patients with information ${ }^{(4)}$, indicating that the involvement of the justice system in health has been changing the way medical assistance is provided.

Increased access to information leads to higher patient expectations regarding diagnosis and treatment. Instead of advancing patient care, avoiding unnecessary procedures overdiagnosis -, physicians tend to practice medicine in a defensive way, known as "clinical judicial syndrome"(5), to protect themselves against possible mistakes.

The social consequences of error and its judicialization are also rarely discussed scientifically. Committing an error may be considered a stressful event and responsible professionals tend to receive no mental health assistance, which leads them to developing individual fighting strategies which are not always efficient in minimizing trauma ${ }^{(5)}$.

Little is known about the legal consequences of error on the daily life of nursing professionals, including its social impacts on workers. Incipient literature on how such error lawsuits are being conducted in Brazil and a view of safety culture which is unfavorable to communication of failure ${ }^{(1)}$ lead to questions about the social implications of errors to the nursing team. A question is thus posed: how do nursing professionals understand the experience of judicialization of errors related to their assistance? Such question aims at understanding the experience of judicialization of error from the viewpoint of nursing professionals.

\section{METHOD}

\section{Design OF STUDY}

Descriptive exploratory qualitative study.

\section{Population}

Nursing professionals (nurses, nursing technicians, and nursing auxiliaries) judged by the justice system of a state in southern Brazil for charges of error in their professional practice. Inclusion criteria were to have been prosecuted for an error involving the work process, in any time frame, with a sentence which cannot be appealed.

Initial approach of participants was mediated by the state's Regional Nursing Council (COREn), which, after authorizing the research, forwarded electronic correspondence with an invitation to all nursing professionals with an active register in the council. It should be emphasized that there is no data on the exact number of messages sent by COREn; therefore, approached professionals were quantified by contact of possible participants with the researchers.

The correspondence presented the research objectives, as well as the researcher's contact information, so that those who agreed to participate in the study would contact her. Thus, only professionals who felt comfortable to participate in the study would keep in touch.

Recruitment was conducted in three different moments from January 2018 to June 2018, contemplating different possibilities for participation. In the first recruitment, 303 professionals answered to the invitation; 67 of them did not authorize further contact. From the 236 who did, eight did not supply enough data for contact to be established. The researcher thus contacted 228 professionals. In this occasion, further details on the study's objective were provided, as well as a strategy for data collection and the intended type of participation. The question whether the participant had been sued for error during exercise of their nursing profession was also posed.

In the second recruitment, only seven out of 228 professionals who got in touch with the researcher met the previously established inclusion criterion, i.e., to have been prosecuted due to error while performing their function. At that moment, plans included conducting in-person interviews according to each participant's availability and regardless of the municipality they were currently living in. However, out of seven, two immediately refused to take part in the study and the other three did not reply. Out of the other two, one did not accept the interview to be recorded and the other did not authorize provided information to be used in the study.

Considering the withdrawals, as a last option, the five professionals which had not initially refused study participation were asked to answer an online anonymous survey. Out of seven, only two replied. The survey is emphasized as containing no characterization questions, seeking to maintain participant anonymity.

Psychological support by a professional licensed and registered in the Regional Psychology Council was provided throughout the study period, although not requested by any professional. 


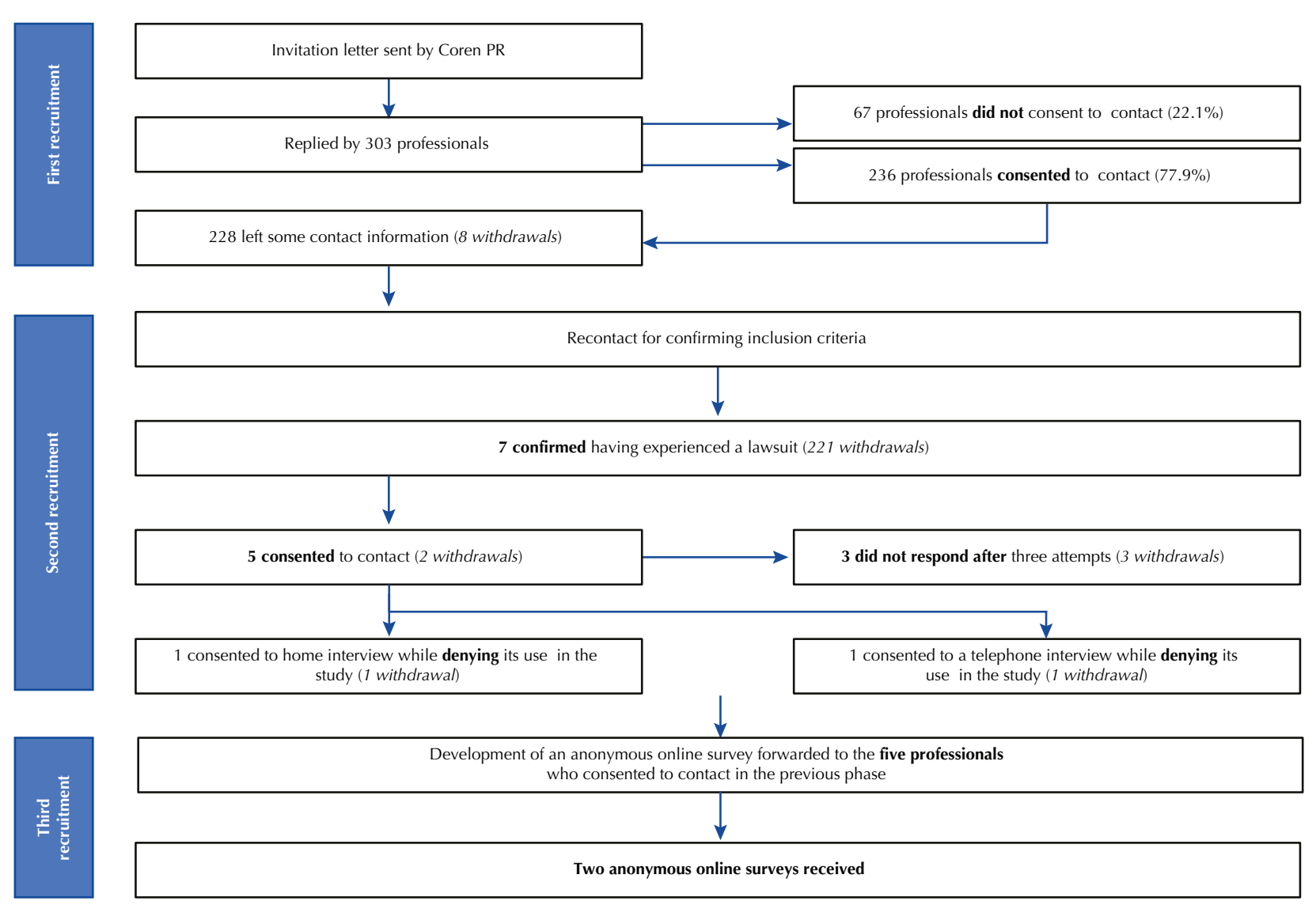

Figure 1 - Participant recruitment flowchart.

\section{Data collection}

Collection was performed through Google Forms platform in an open-ended online survey, with no sociodemographic characterization items, and guided by the following question: "Tell me about your experience with judicialization of error in your professional practice". The supporting questions "To which factors do you attribute the error in your professional practice?", "Have you received backup/support from your immediate supervisors, unit managers, unions and professional associations? How was it?" and "Did this error influence your professional practice or social life? Tell me about it" were used to identify how institutional support was provided during the lawsuit and further perspectives in the profession.

\section{Data tREATMENT AND ANALYSIS}

Treatment of the interview material followed the Oral History technique, whose steps are transcription, textualization, and transcreation ${ }^{(6)}$.

Initially, the data were transferred to a Microsoft Word file, including the guiding questions. In the second phase, textualization, the questions were removed from the text, which acquired a narrative character. Finally, transcreation was performed; in this phase, the text is organized into paragraphs $^{(6)}$ resulting from each participant's textual reports. Textual reports are emphasized not to have been returned to the participants for final approval, due to interview anonymity. Statements are thus unaltered and textual insertions by the author are marked by brackets.

For data analysis, two symbols associated to resilience were chosen to identify the participants - Lotus Flower and Phoenix. Lotus Flower was chosen to identify the Nursing Technician participant, who attributes one of the situations leading to her legal experience to institutional power issues, which kept her from acting due to fear. The second participant, here named Phoenix, was prosecuted due to institutional power relations while preparing for retirement. Although she was the hospital's technical manager, she received no support from the organization or union.

\section{ETHICAL ASPECTS}

All ethical requirements have been respected during the conduction of this research, as recommended by Resolution n. $466 / 12$, by the National Health Council. The project has been approved in Opinion no 2.450.997, dated December 20, 2017, by the Permanent Ethics Committee of Research Involving Human Subjects of Universidade Estadual de Maringá, Paraná state.

\section{RESULTS}

Both nursing professionals focused on the experience of error during their narratives. Lotus Flower's narrative 
suggests suffering due to inertia or her lack of action in preventing the error from following its development course.

I have been in the health area since 2005. For five years I have worked at a First Aid Post and it has been eight years working at the Surgical Center. [My insertion in the labor market] was as an intern in the First Aid Post [and the area in which I feel more confident to work] is the Surgical Center. [Concerning the experience of error in my practice,] it is very hard. I am a witness in two legal suits. In one of them, my colleague provided dipyrone to an allergic patient, who died; in the other, the gynecologist on duty provided unsuccessful spinal anesthesia to a pregnant woman and the patient died as well. In this second case, I blame myself. The physician [gynecologist] did not let us nurses call the anesthesiologist because it was the small hours. It was a tragedy! As a nursing technician, I had no courage to refuse. I made a mistake! Now I know I should have refused. [I attribute my error to] a lack of attention in the first case and, in the second, to the physician's rashness and impatience and to myself, because of fear. [Undergoing a lawsuit] is hard and sad, we get very put off. I was supported by the health union, perhaps because it was a criminal suit. [The mistake has influenced professional practice]. Yes, there is no way it could not have. By seeing so many lives taken away and being able to do nothing, in your professional practice, you start seeing things in a different way, you become more observant and do not always consent to everything you are told. [Concerning my future in nursing,] I intend to stay in the area, increasingly observant, to study more and fight for nursing rights (Lotus Flower).

Phoenix's narrative is marked by a feeling of being unsupported by institutions and professional associations, which resulted in a perception of injustice, shame, and revolt in her experience of judicialization.

I graduated 43 years ago. I worked as an assistant nurse in an Urgency Service and Intensive Therapy Unit. I was the nursing director for two hospital institutions, seven years for an oncology hospital and 8 years for a university hospital. During all these years I always had two employment relationships, one with hospital institutions and the other with universities. I have been thus a university professor for 43 years. I joined [the labor market] pretty early, being hired both in the Emergency Service and a private university to follow interns in the First Aid Post. [The area in which I feel most confident to work] is currently teaching and doing research. [I have experienced practice errors] many times, but it was all solved in the work environment. My professional life was most impacted when I was the nursing director of a university hospital and technical responsible for the nursing team. The patient was downgraded in the Recovery Room after extubation with bradycardia and the cardiac monitor alarm did not sound. It was the time of the day when on-duty workers were changing shifts; the Surgical Center nurse who was also responsible for the Post-Anesthesia Recovery Room had left earlier to go to the doctor, because she had a high-risk pregnancy. So, the Central Supply nurse took up her activities as well. When the patient presented a complication, the nurse was called to support the nursing auxiliary who was in Post-anesthesia Recovery. The anesthetist had already left, and the complication was attended by a first-year medical resident. So, it was a high-risk service and the patient acquired neurological sequels which damaged his speech. With five other nurses and two nursing auxiliaries, I was sued by Coren. [I attribute the error to] a lack of human resources and outdated cardiac monitoring equipment. It was impactful, because I was not present during the adverse event and even so I had to respond as the technical manager. We spent a lot of money to hire a lawyer, because the institution did not support us in any aspect, neither financial nor legal. I faced charges for five years. In the hearings with Cofen we were humiliated because they asked us how we could be a hospital that trained human resources and caused harm to patients. Even though the lawyer provided arguments, showing many probative documents, we were very much humiliated. Finally, we were sued and had to pay a fine and our names were published in Cofen's website and journal as offender professionals. We appealed to Cofen, which absolved us after two years. The [hospital] institution neither supported us legally nor provided emotional support or orientation on how to proceed in the hearings. Since the nursing auxiliaries could not pay the lawyers we hired together, they were defended for free by the local health union's lawyer and were well represented. The counsellors of Cofen and its president were then pleased to humiliate us in the audiences. I was very upset at the time, outraged at the institution, because I was finishing my term as a nursing director. I faced all of the charges when I was no longer a member of the institution. Today this serves as an experience to tell my students and residents in the classroom. I am in a pre-retirement phase and I see in my professional practice supervising residents that adverse events and errors are more currently notified, since the patient safety policy suggests errors be communicated with no punishment, but I still see that professionals are afraid of communicating adverse events. Cofen itself has suggested the implementation of this policy for communication of adverse events, but I think it is still going to take a long time for this practice to become effective and shared with relatives and patients (Phoenix).

Although Lotus and Phoenix associate negative feelings to judicialization, both seem to have used this experience as a motivational and impelling factor for their dedication to professional life in nursing.

\section{DISCUSSION}

Deficiencies attributed to a health system which is often flawed lead to the increasingly common phenomenon of judicialization. These may be associated to an unmaintained system, flawed management or low quality and efficiency of the assistance processes ${ }^{(7)}$. Such situations lead to an increase in the search for guaranteeing the right to health through justice, causing other problems to the system, such as using financial resources inappropriately ${ }^{(7)}$ or suffering of health workers undergoing this situation.

Occurrence of errors is unavoidable and fighting them, not only as professionals, but also as complex individuals who have feelings, results in a decreased confidence in quality of assistance, creating thus defensive practices in the work environment, in which the focus may not be quality, but legal backup $^{(5)}$.Also, charges of inappropriate professional practice 
increase stress and reduce career satisfaction ${ }^{(3)}$. A study conducted in Belgium with nurses and physicians has shown that participation in incidents causing damage to patient safety may be a predictor for problematic use of medication, risk of burnout, and abandonment of the profession ${ }^{(8)}$.

Errors leading to judicialization identified in this study include those related to medication and birth assistance (Lotus Flower) and post-operative care (Phoenix). Medication errors have been broadly reported in the literature. However, in nursing teams, the consequences of errors for professionals almost always lead to negative situations, such as being fired, relocation to another sector, and administrative suit ${ }^{(9)}$.

The participant identified as Lotus Flower has shown more grief when reporting her experience of error in birth assistance, associating the patient's death to a feeling of omission. A study investigating coping in obstetricians and nurses involved in adverse events in the birth room reports feelings of regret, shame, and existential worry ${ }^{(10)}$. In this study, half the participants reported that, after experiencing a traumatic birth, they started to reflect more on the meaning of life and more than half (65\%) identified professional improvement ${ }^{(10)}$. On this account, Lotus Flower reported that her desire for constant professional development has bloomed, showing that the incident experience made her more attentive towards working, breaking the barrier of fear to stand up when facing situations of risk.

Lotus Flower's difficulty in standing up against the medical professional's attitude, which put the life of a patient at risk and resulted in death, may be justified by cultural issues that associate subordination of nursing to medical hegemony. In this perspective, the autonomy of nursing professionals is discussed in the literature, since difficulties in breaking with the biomedical paradigm and centralization of a curative model of care, which make validation of nursing difficult, are still observed ${ }^{(11)}$.

A study which sought to identify the perceptions of postgraduate students and professors regarding the actions of nurses as political and social beings concluded that nursing as a profession still preserves traces from its history, which was based on submission, and is still in a phase of developing consciousness to transform its practice ${ }^{(11)}$. In this perspective, Lotus Flower started using her traumatic experience as a propulsive element for understanding her role in nursing, transforming thus her professional record.

The hesitation in emphatically standing up observed in Lotus Flower's report may be an attitude reinforced among nursing academics since their education. As an example of this, a study aimed at understanding resistance strategies adopted by nursing students in situations of moral suffering has provided reports in which professionals kept academics from providing care, including vital signs assessment, due to physicians allowing only medicine academics to provide care to their patients ${ }^{(12)}$. Such attitudes ought to be eliminated, since they seem to normalize and strengthen hegemonic practices from the medical category which make resistance by nursing workers in morally inappropriate situations more difficult ${ }^{(12)}$.
Questioning the (lack of) attitude by Lotus Flower may lead to a reflection on the historical, cultural and political process of nursing, enabling action towards creating strategies which allow for breaking with the past, which is associated to mere submission, reaffirming thus the autonomy of nursing professionals.

By its turn, Phoenix's report refers to an error related to care in the post-anesthesia recovery period which is attributed to a deficient structure, i.e., a lack of human resources and an outdated cardiac monitor. This is increasingly true of Brazilian public health systems and was also identified in a study which analyzed the perception of health managers on regional planning of municipalities. In such investigation, the lack of human and financial resources was found to make health planning unfeasible ${ }^{(13)}$. Although at the time of her experience with judicialization Phoenix was a nursing manager for the hospital, providence of human and material resources is clearly beyond the reach of her actions as a supervisor.

Concerning human resources, the maintenance of an appropriate nursing staff size has been appointed as a challenge not only for Surgical Centers ${ }^{(14)}$. Exemplifying difficulties related to human resources in all of the healthcare network, a study conducted in Rio Grande do Sul state with nursing professionals from primary and tertiary attention has found that lack of physical structure and equipment and an excessive number of patients per professional are risk factors for the occurrence of moral suffering among nurses ${ }^{(15)}$.

Although risks to mental health related to stress and moral suffering of professionals who commit errors are known, both reports identified a lack of backing/support from the health service and professional associations. This condition is pointed in the literature ${ }^{(1)}$ as an impeding factor for error communication, reinforcing the need for thinking of alternative solutions to fight adverse events through implementing a fair safety culture.

The Federal and Regional Nursing Councils, as organizations responsible for normalizing and inspecting nursing, have no legal obligation of providing legal assistance to professionals; this function is attributed to the union. However, from Phoenix's report, the difference between actions of each organization are verified to be perhaps unclear in the imagination of nursing workers, which suggests the need for a better promotion of their activities. Also, councils are conjectured to be links integrating the professional category and the justice system, supporting the former, to enable broader analyses with an educational approach, as opposed to the punitive outlook reported by Phoenix.

Although the possibility of using the professional association as a form of support to professionals judged for error is considered, Phoenix's statement should be particularly emphasized: it reports the worsening of emotional suffering associated to judgment from part of this organization's representatives. The preparation of their counsellors to deal with situations of conflict, such as judicialization, is thus questioned.

Despite the feelings of sadness, injustice, and even revolt identified in the reports, the professionals stayed in their area 
and sought self-development and improved quality for their work. Similarly, a study which investigated cases of moral suffering among 268 nurses found that, although half the participants had been through situations of moral suffering once or more times in their practice, $63.1 \%$ affirmed they would not abandon their work for this reason or, if they did, would seek to work in something similar ${ }^{(15)}$. Such information may indicate that nursing professionals have a higher capacity of resilience at work.

Opting for confronting a stressful situation which causes moral suffering without abandoning the profession demonstrates the participants' resilience and their conviction in career choice. An integrative review which investigated resilience in studies on workers' health emphasizes the importance of understanding factors which strengthen the resilience of health workers and fostering this skill in the formation of professionals as a strategy for confronting psychic suffering ${ }^{(16)}$.
Even limited to a Brazilian state and with the participation of only two professionals, this investigation's reports foster knowledge on the hidden experience of workers sued for error involving nursing, providing bases for planning support networks for safe care and mental health of professionals. Also, it enables broadening the discussion of errors in the health area, as well as its causes and consequences.

\section{CONCLUSION}

The social implications of the judicialization of error to the daily life of nursing professionals include emotional suffering, revealed by a feeling of omission and lack of support in confronting a lawsuit. Employment relationships did not lead to the organization of a support network which backed the participants in their experience of judicialization. Although the conjunction of these factors has made the experience contentious, professionals' resilience is emphasized; and through hope, they stayed and self-developed in their profession.

\section{RESUMO}

Objetivo: Compreender a experiência da judicialização por erro sob a ótica do profissional de enfermagem. Método: Estudo qualitativo com duas profissionais de enfermagem processadas por erro em um Estado do sul do Brasil. Os dados foram coletados entre janeiro e junho de 2018, através de questionário on-line, e analisados por meio da técnica da História Oral. Resultados: Os relatos abordaram a vivência do erro e sua influência na prática profissional. A percepção de não ter conseguido intervir na ocorrência do erro e a falta de apoio institucional e dos órgãos de classe foram mencionados como causadores de sofrimento emocional, sentimento de injustiça e de revolta. Apesar disso, ambas mencionaram apoio do sindicato de saúde local e a esperança de se manter na profissão. Conclusão: $\mathrm{O}$ sofrimento emocional causado pela judicialização é potencializado pelo sentimento de impotência na prevenção do erro e pela falta de apoio institucional.

\section{DESCRITORES}

Enfermagem; Danos ao Paciente; Segurança do Paciente; Legislação de Enfermagem; Estresse Psicológico; Saúde do Trabalhador.

\section{RESUMEN}

Objetivo: Comprender la experiencia de la judicialización del error desde el punto de vista del profesional de enfermería. Método: Estudio cualitativo con dos profesionales de enfermería procesadas por error en un estado del sur de Brasil. Los datos se recogieron entre enero y junio de 2018 a través de un cuestionario en línea y se analizaron mediante la técnica de la Historia Oral. Resultados: Los informes se acercaron de la experiencia del error y su influencia en la práctica profesional. Se mencionó la percepción de no haber logrado intervenir en la ocurrencia del error y la falta de apoyo institucional y de organizaciones de clase como causa de sufrimiento emocional, sentimiento de injusticia y revuelta. A pesar de ello, ambas mencionaron el apoyo del sindicato local de la salud y la esperanza de permanecer en la profesión. Conclusión: El sufrimiento emocional causado por la judicialización se agrava por un sentimiento de impotencia para evitar el error y la falta de apoyo institucional.

\section{DESCRIPTORES}

Enfermería; Daño del Paciente; Seguridad del Paciente; Legislación de Enfermería; Strés Psicológico; Salud Laboral.

\section{REFERENCES}

1. Souza VS, Inoue KC, Costa MAR, Oliveira JLC, Marcon SS, Matsuda LM. Nursing errors in the medication process: television electronic media analysis. Esc Anna Nery. 2018;22(2):e20170306. doi: https:doi.org/10.1590/2177-9465-ean-2017-0306

2. Fontana RT, Wolf J, Rodrigues FCP, Castro LM. Documentary analysis of written media on adverse events occurring in practice nursing. Rev Enferm UFPE On line. 2015;9 Suppl 4:8103-10. doi: 10.5205/reuol.6235-53495-1-RV.0904supl201516

3. Hwang $\mathrm{CY}, \mathrm{Wu} \mathrm{CH}$, Cheng FC, Yen YL, Wu KH. A 12-year analysis of closed medical malpractice claims of the Taiwan civil court: a retrospective study. Medicine (Baltimore). 2018; 97(13):e0237. doi: 10.1097/MD.0000000000010237

4. Dugleux E, Rached H, Rougé-Maillart C. Proof of patient information: analysis of 201 judicial decisions. Orthop Traumatol Surg Res. 2018;104(3):289-93. doi: 10.1016/j.otsr.2017.12.017

5. Pellino IM, Pellino G. Consequences of defensive medicine, second victims, and clinical-judicial syndrome on surgeons' medical practice and on health service. Updates Surg. 2015;67(4):331-7. doi: 10.1007/s13304-015-0338-8

6. Meihy JCSB, Holanda F. História oral: como fazer, como pensar. $2^{\text {a }}$ ed. São Paulo: Contexto; 2014.

7. Polakiewicz RR, Tavares CMM. Vulnerabilidades e potencialidades da judicialização da saúde: uma revisão integrativa. Rev Enferm Atual Derme. 2018;84:135-56. doi: http://dx.doi.org/10.31011/1519-339X.2018a18n84.11

8. Gerven EV, Elst VT, Vandenbroeck S, Dierickx S, Euwema M, Sermeus W, et al. Incresead risk of burnout for physicians and nurses involved in a patient safety incident. Med Care. 2016;54(10):937-43. doi: 10.1097/MLR.0000000000000582 
9. Morrudo EQ, Figueiredo PP, Silveira RS, Barlem JGT, Oliveira SG, Ramos FC. Errors in medicinal therapy and the consequences for nursing. Rev Pesq Cuid Fundam Online. 2019;11(1):88-96. doi: https//dx.doi.org/109789/2175-5361.rpcfo.v11.6477

10. Schrøder K, Jørgensen JS, Lamont RF, Hvidt NC. Blame and guilt - a mixed methods study of obstetricians' and midwives' experiences and existential considerations after involvement in traumatic childbirth. Acta Obstet Gynecol Scand. 2016;95(7):735-45. doi: 10.1111/ aogs.12897

11. Magagnin AB, Aires LCP, Freitas MA, Heidemann ITSB, Maia ARCR. The nurse as a political-social being: perspectives of a profession in transformation. Ciênc Cuid Saúde. 2018;17(1):1-7. doi: 10.4025cienccuidsaude.v17il.39575

12. Bordignon SS, Lunardi VL, Barlem EL, Silveira RS, Ramos FR, Dalmolin GL, et al. Nursing students facing moral distress: strategies of resistance. Rev Bras Enferm. 2018;71 Suppl 4:1760-7. doi: https://doi.org/10.1590/0034-7167-2017-0072

13. Ferreira J, Celuppi IC, Baseggio L, Geremia DS, Madureira VSF, Souza JB. Planejamento regional dos serviços de saúde: o que dizem os gestores? Saúde Soc. 2018;27(1):69-79. doi: https://doi.org/10.1590/s0104-129002018170296

14. Candido SEA, Côrtes MR, Truzzi OMS, Sacomano Neto M. Fields in organization studies: relational approaches? Gest Prod. 2018;25(1):6880. doi: https://doi.org/10.1590/0104-530x2122-16

15. Schaefer R, Zoboli ELCP, Vieira M. Moral distress in nurses: a description of the risks for professionals. Texto Contexto Enferm. 2018;27(4):e4020017. doi: https://doi.org/10.1590/0104-07072018004020017

16. Cruz EJER, Souza NVDO, Amorim LKA, Pires AS, Gonçalves FGA, Cunha LP. Resilience as an object of study of occupational health: narrative review. Rev Pesq Cuid Fund Online. 2018;10(1):283-87. doi: http://dx.doi.org/10.9789/2175-5361.2018.v10il.283-287 